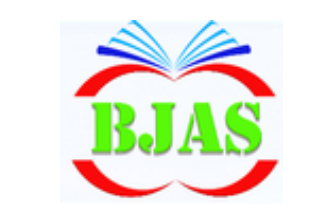

ISSN $1814-5868$
Available online at http://bjas.bajas.edu.iq

https://doi.org/10.37077/25200860.2020.33.1.05

College of Agriculture, University of Basrah

Basrah J. Agric. Sci., 33(1): 50-67, 2020

\section{Basrah Journal of Agricultural Sciences}

E-ISSN: 2520-0860

\title{
Planning and Optimal Design of the Outdoor Open Spaces of Kindergartens in Basrah Governorate, Iraq: A case study of Al - Yassemin and Al-Ashar Kindergartens
}

\author{
Zahraa A.N. Al Thiabi* \& Samira M.S. Al-Samray \\ Department of Horticulture and Landscape, College of Agriculture, University of Basrah, \\ Iraq \\ *Corresponding author e-mail: zahraa.abdullah.n@gmail.com \\ Received 19 September 2019; Accepted 16 December 2019; Available online 26 June 2020
}

\begin{abstract}
Kindergarten buildings play an important role in society for their roles in the rehabilitation of children before joining the primary stage to fit the development of the educational process., They are considered the first real social establishment organizing and preparing the child for the outdoor world to show his personal creative and intellectual energy .The relationship between the kindergarten building and its open spaces and its impact on increasing the cultural and social awareness are reflected successfully on the educational communication of children. The researcher has presented the proposed designs using modern technical program (AutoCAD) and she hopes that this study will be a part of future plans in the planning and designing of open spaces of kindergarten buildings including comprehensive basics and international standards of childhood.
\end{abstract}

Keywords: Kindergarten Outdoor Space, Design optimized for kindergarten, Design proposals.

\section{Introduction}

Kindergarten is one of the most important social institutions. It is the second field after the family, which contributes to instill the assets of dealing with people and preserve the surrounding environment, and it is one of the important educational stages that contribute effectively to the development of children's mental, physical, behavioral and emotional abilities. Kindergarten is keen to instill the development of the child's technical and aesthetic skills with the provision of information to make it able to continue primary education and organize the times of playing, food, picnics, rests and teaching hygiene (AlNawaiseh \& Qatawneh, 2015).

Planning, designing and organizing the outdoor spaces of a kindergarten in accordance with the nature of the pre-school require things that greatly affect the appetite and attraction of children and their love for the place, like providing playgrounds and safe corridors with appropriate colors, materials and tools. these requirements contribute to evoke the creative energies in children with attention to natural components with the coordination and cultivation of plants and green areas, which are 
Al Thiabi \& Al-Samray / Basrah J. Agric. Sci., 33(1): 50-67, 2020

considered as useful factors in creating good climate to achieve the goals of kindergarten in the education of children (Mardan et al., 2004).

Recent trends in the education of pre-school children emphasize the need to pay attention to the environment of the kindergarten buildings where the environmental design is concerned with the provision of water and agricultural and other areas for the pets which achieve a living and suitable environment full of sensory stimuli to encourage social interaction among children. This environment will contribute to the development of all the abilities and skills from the part of the healthy environment in addition to the development of environmental awareness (Franck, 1985).

This research is the first in its kind in Iraq which lacks local Arabic studies that address the environment of the outdoor spaces and gardens of kindergarten buildings because it deals with a large group of society with critical age. The results of this study is important for policymakers, supervisors and educators in order to ensure the provision of an ideal learning environment with a modern vision and advanced education away from the traditional system in educational programs.

\section{Research aims}

1-Evaluating the status of the elected kindergarten buildings and identifying the most important design and functional problems they are experiencing.

2-Developing suitable designs for the outdoor spaces and gardens of kindergarten schools from environmental, aesthetic and functional points of view , suitable to the environmental conditions of Basrah governorate.

\section{General Concept of Outdoor Space}

Open spaces are related to different human activities external spaces are determined by planning the formation of open spaces for the surrounding buildings. They generate the external spaces (Marlowe, 1977).

Outdoor space is defined as the relationship between mass and space, or it is the space system consisting of the distribution of blocks in space and is surrounded by surfaces. Outdoor space is also defined as the relationship of architecture with its neighbors and that this term is in line with the concept of art as it reflects the integration of 'Earth, water, plant and paving and others' with each other and not having them work isolated from each other and this shows them as a beautiful piece of art (Dober, 2000).

\section{Open spaces for kindergartens:}

Outdoor space is a part of the educational space because it achieves aesthetic standards, activities and learning. It is a place for observation and experimentation, therefore planning, designing and preparing it with care and experience helps the child to acquire constructive environmental, social and psychological behaviors.

The diversity of tools, devices and games ensures that the child's sensory and motor desires are met. Child experiences and adapting to new situations to support his sensory and motor development to know the possibilities of the surrounding location in space without violating the rules of life within the group, because individual and group behaviors can differ from what exists in the internal space. A safe use of all devices and games can develop the child's motor abilities and enrich his 
Al Thiabi \& Al-Samray / Basrah J. Agric. Sci., 33(1): 50-67, 2020

relationships with members of the group of children (Yıldırım \& Akamca, 2017).

\section{Modern Concept of Outdoor Space for the kindergarten}

This concept is based on learning by playing and free activity and is centered on the areas of its development and seeks to acquire the child creative, analytical and critical thinking skills, regardless of the content of the study or information acquired by the child as the information of a nature of change, while thinking skills remain constant. In other words, the curriculum develops in children the skill of (how to learn) in addition to the development of motor skills with self-initiative in education through research, exploration, attempt and error (Bloom, 1956).

\section{Classification of open spaces for kindergartens}

\section{1-Gardens}

The garden is considered the most important part of the open spaces of the kindergarten building. The most important thing that distinguishes the kindergarten is the garden ; the place where children grow like small plants through their need at this stage to the garden to run, play and jump around ,because their growth is through movement and activity due to the opinion of "Friedrich Froebel" As a founder of kindergarten he considered the child in the kindergarten like a (human flower) needs a suitable natural environment to take care of the child as a gardener who understands the characteristics of the flower and the specifications of the natural environment suitable for them .This gardener helps him to discover his talents and abilities and increase his acquisition of concepts, skills , behavioral habits and positive Vision to protect this environment (Al-Lagany, 1989).

\section{Classification of gardens in kindergartens}

\section{A-Entrance garden}

The entrance to the kindergarten building should be full of vitality and exciting colors which are attractive for the child regardless of the space allocated for the entrance garden with the provision of space for colorful flowers and potted flowers to add aesthetic touch to the entrance with a little colorful gravel to prove the artistic sense and to attract the attention of visitors of the children and their families .It is possible to add a small fountain or symbols of some geometric shapes like stone balls...etc.

\section{$\mathrm{B}$-The main garden}

It is very important for the kindergarten building in terms of aesthetic, environmental and functional for the child, because of its benefits on the integrated growth of the child's personality through playing and interaction in a healthy and pure atmosphere and natural air. The main garden should include various plants and trees, shrubs, green areas, water and places for sitting to rest and learn in nature where there is a fertile environment to provide children with many concepts, skills and environmental behavior desired to develop a sense of wonder about the elements of the natural environment that surrounds them. Kindergarten garden is an ecological spaces for real life and beautiful space and flexible environmental data to attract birds, butterflies and insects that inspire creativity and promote a sense of responsibility and love of nature and support the emotional, cognitive and social needs of the child (Taylor et al., 1998).

\section{2-Main outdoor arena}


The outdoor space is of a great importance in the daily life of kindergarten children. They unload their physical activity through playing which is characterized by jogging, climbing, jumping and walking freely and where children interact with each other and exercise their social and motor skills through movement to identify the surrounding space, which enables them to estimate distances. The outdoor space arena helps children to synergy with the movement of the hand and foot movement for children to include the physical and psychological field together. The children playing in groups in the external arena gain them various habits and values in life, such as cooperation, participation, self-confidence, venting for emotions, waiting for the role and discovering their abilities, their enjoyment of good health and an integrated body. The exposure to sunlight and air in this arena will help to kill some types of viruses and contribute to the prevention of diseases. The outdoor arena is not only for free games, but is an extension of the natural environment (gardens) through which they employ games and activities in an exciting and safe way that gives children more learning opportunities that help them to enrich their educational program.

\section{3-External corridors and walkways for kindergarten buildings:}

Corridors and walkways are the arteries that lead to the places of kindergarten outside and playing areas and gardens and the most important specifications are

A- The corridors should be flat and of adequate width, free of obstacles.

B- It is preferred to allow children to make their own paths by leaving a special space for the innate playing. Avoid designing lanes for each distance as a specific path.

C- The spaces between the games in the yards of the outdoor environment should be sufficient to allow children to move easily.

D- The presence of signs indicating childhood to facilitate understanding by children in the external environment to determine the safe movement of tracks.

\section{4-Flooring for external sites of kindergarten buildings}

General specifications of floors are: -

A- The colors should be as light as possible and do not cause inconvenience to the children through playing games.

B- The floors should be flat .If they are tilted, it is preferable to have low and little thresholds with very low altitudes.

C-The floor should be selected of high durability non-skid and of moderate cost (Khalaf, 2015).

\section{Field study}

The field study included three stages:

The first phase: studying and analyzing the field reality of the selected samples through repeated field- visits and surveying sample sites with the preparation of illustrative schemes for the samples of the study elected, because the researcher did not get the design schemes and building style.

The second phase: Preparation of a questionnaire for the members of the research sample in order to collect information on the external environment of open spaces and analysis of the results derived from the questionnaire vocabulary, based on appropriate 
statistical methods and discussion of the results obtained.

The third phase: Determining the design proposals for the selected outdoor spaces taking into consideration the available possibilities.

\section{General description of research samples}

1-Name: Al-Ashar kindergarten.

Location: Jubaylah.

Area: $3000 \mathrm{~m}^{2}$ (Fig. 1, Scheme 1).

Number of pupils: 452.

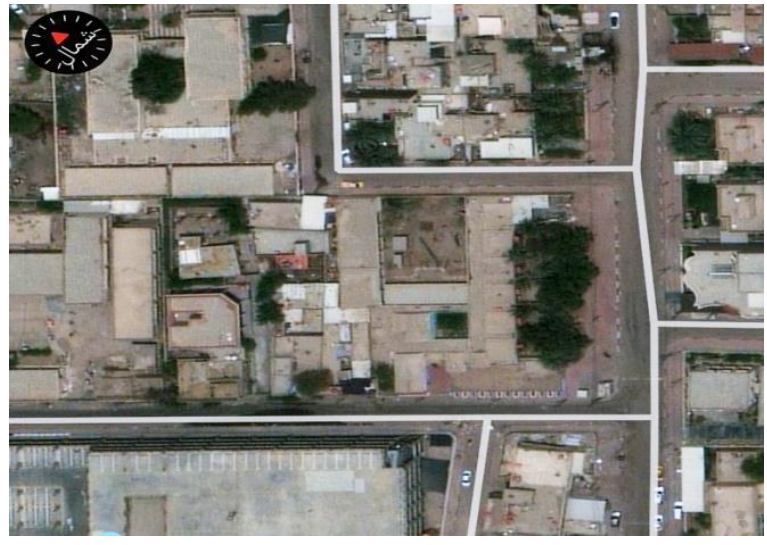

Fig. (1): Show the geographic location.

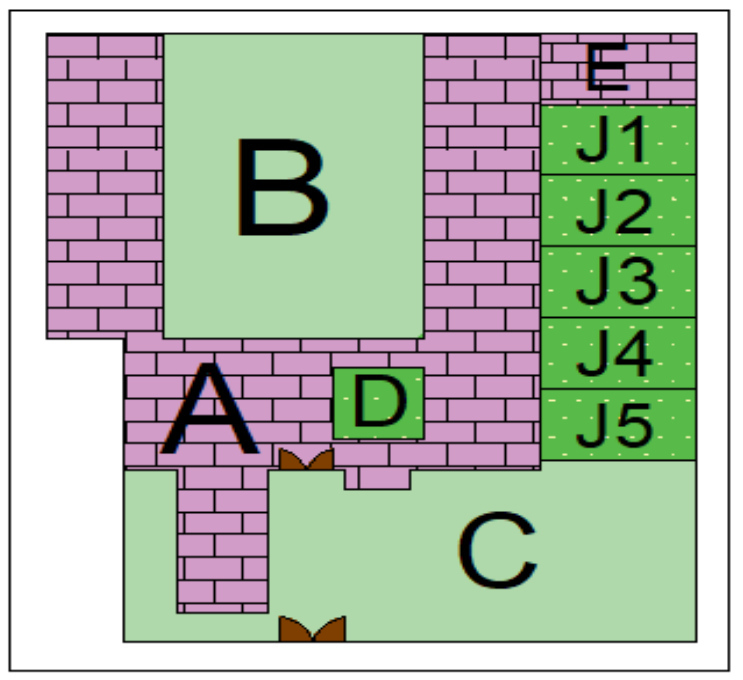

Scheme (1): Shows the design style of AlAshar kindergarten (source: the researcher). A: The building block, B: The back of outdoor space, $\mathrm{C}$ : The front part of outdoor space, D: The inner courtyard, E: The guard's dwelling, J (1-5): Inner courtyard.

\section{1. Design idea:}

The building consists of one floor and one main gate, the building is old and has a distinctive design where the building consists of five basic rows. Each of them has a private garden located on the right side of the row and overlooking the garden through a large window and door.

The whole size of the building is about $38 \%$ of the area of the site.

The building contains between its sides a large garden used as a corner of the sand.

\section{2. General Analysis for the location}

\subsubsection{Entrances}

Monitoring of the site which has one main wide entrance. It is rather broad and traditional. It is unattractive to children.

\subsection{Adjacent to the site}

Kindergarten overlooking from three sides on a service street width $(10 \mathrm{~m})$. It has a privileged location adjacent to the site from three sides of the main streets. On the left of the site, there are residential buildings. There is a building under construction with several floors overlooking on the front.

\subsection{Elements of open spaces}

\subsection{1: Gardens:}

Through the field survey of the site, the researcher recorded that the building contains:

A- A side garden located behind each row (five separate gardens) area of $84 \mathrm{~m}$ each as a distinctive style of design was seen a number of palm trees which are neglected. 
B- A small indoor courtyard of $49 \mathrm{~m}$ planted with undeveloped mud plants

\subsection{2 -Traffic paths (corridors and walkways)}

A corridor linking the main gate of the site to the building gate was seen on the site.

\subsubsection{Educational places outside}

The indoor garden was a total area of sand corner and interspersed with a set of tires for exploratory play.

\section{4. Natural and Structural Ingredients}

\subsubsection{Natural ingredients}

A-Plants: The following plants were registered:

Conocarpus (Cynodon dactylon, Palm trees (Phoenix dactylifera) and Jungle plants.

B- Sand:

Sand has occupied the largest proportion of the outdoor space, where it occupied the indoor garden as a whole and an area of $600 \mathrm{~m}$

\subsection{2- Structural Components}

No structural components such as fountains, small basins or statues were observed in outdoor space. The site also lacked furniture in outdoor space such as benches, tables, umbrellas, arches and tables.

\section{5- The following games were monitored}

Games skating number 4, Swing games number 2, Balance games number 2, Tires for exploratory play number 2 , Basketball column

\section{Name: Kindergarten Al -Yassemin}

Location: Mishraq area

Area: $3150 \mathrm{~m}^{2}$ (Fig. 2, scheme 2).

Number of pupils: 702.

\section{1. Design Idea:}

The building consists of one floor It is of modern design, The building block mediates the total area of the site It constitutes about $38 \%$ of the total area. The researcher also noted that the building was redesigned.

\section{2. General Site Analysis:}

\section{2. 1. Entrances:}

The site has two main front entrances, one of which is in the middle of the front of the site and the other is on the same direction, but takes the right of the front of the site.

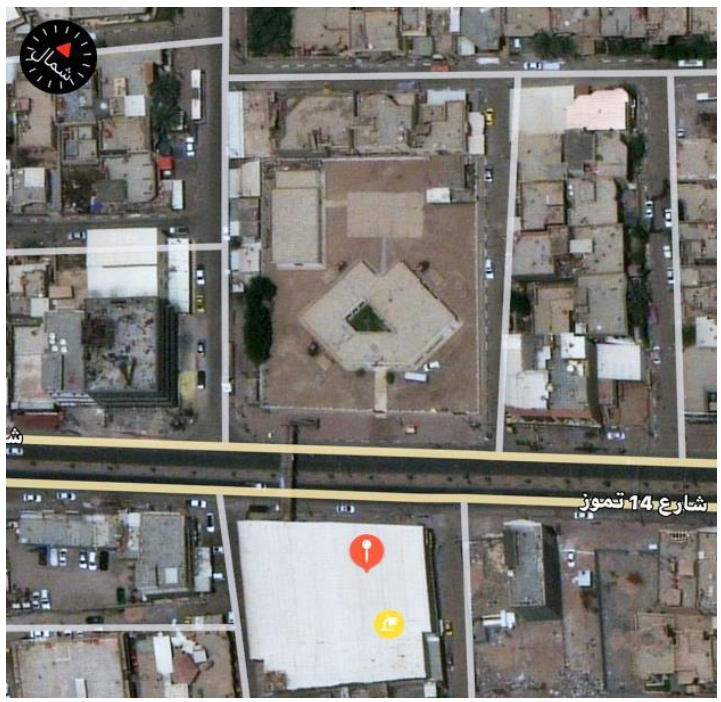

Fig. (2): Show the geographic location of Al Yassemin kindergarten.

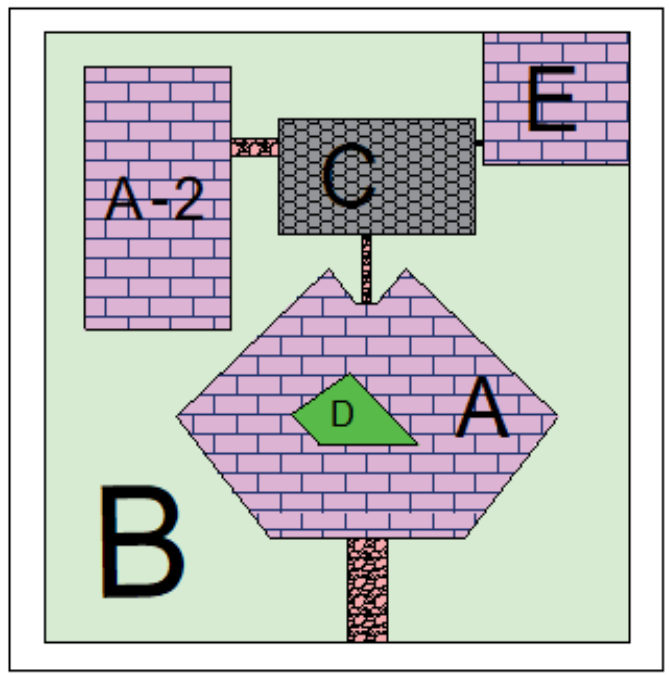


Al Thiabi \& Al-Samray / Basrah J. Agric. Sci., 33(1): 50-67, 2020

Scheme (2): shows the design style of Al Yassemin kindergarten/ source (researcher). A: The building block :A-2: Additional annex to the building block, B: Outdoor space C: The tiled part of outdoor space, D: The inner courtyar and $\mathrm{E}$ : The guard's dwelling.

\section{2. 2. Adjacent to the site:}

Adjacent to the front of the site is the main street with two-way and on the left and right sub-streets (service). The site overlooks on residential buildings of varying heights (2- 3 floors) and high commercial building (5 floors) on the right and back.

\section{3: Elements of open spaces:}

\section{3. 1. Gardens:}

The site lacked green spaces and gardens and the presence of the park was limited to a small inner courtyard with poor plant diversity.

2. 3. 2. Traffic paths (corridors and walkways) When the field survey of the site was made, the existence of corridors was recorded. There was a corridor linking the main entrance of the kindergarten with the entrance to the building of the kindergarten. Also there was another corridor linking the building with the courtyard and tiled third corridor up the courtyard with the outdoor part. But these corridors do not draw attention because they were made of one material; cement. Thus they were boring for children. The tracks were not cared for at the site.

\section{3. 3. External educational spaces}

Outdoor space lacked many components and equipment, including the allocation of educational places, the purpose of which is to communicate the idea and information to the child in a smooth manner.

\section{4. Natural and Structural Ingredients:}

\section{4. 1. Natural ingredients:}

A-Plants: The indoor garden lacked diversity of plant and the content of the garden was limited, so the growth of a number of weeds and bush plants was seen.

B-Sand: The largest area of outdoor space was covered with sand, but no specific corner was used to play or learn.

\section{4. 2. Structural components}

Despite the importance of the structural components (umbrellas, seats, arches) to provide shade to children and add joy and comfort to the child's psychological mood, their presence on the site has been completely diminished.

\subsection{Games}

Outdoor spaces for recreational activities and stadiums were devoiced of any games.

\section{Preparation of the questionnaire}

To achieve the objectives of the study, the researcher decided to build two questionnaires after reviewing the relevant researches and literature as follows:

1. The first questionnaire: It is addressed to the director and teachers of kindergartens in the elected samples in Basrah Province to know their opinions about the needs, constraints and difficulties facing them during the application of educational activities in the external places (gardens and squares external spaces). The reason for choosing this sample for they are the most interactive people with children and the school environment. The sample list included 8 
main dimensions, each of which includes a set of paragraphs to understand the needs of the study.

2. The second questionnaire: It is addressed to kindergarten children of the elected samples in the Province of Basrah to know their desires and take them into consideration when setting designs. Due to the given age group of the children who are prepared to join kindergartens and after taking the viewpoints of the specialists in psychology, the answers to the questionnaire which were represented by pictures seemed expressive and clear to allow the child to express his / her opinion freely. The researcher had to read the questions to the children in a clear and simple way. The questionnaire included 12 paragraphs.

\section{Statistical processing:}

The researcher arranged and organized the paragraphs and the tabulated data and then analyzed the information obtained statistically (Statistical analysis) using the statistical package for the social science (SPSS) and then conducting it for each sample of the questionnaire separately.

\section{Discussion of the survey results:}

1. What do you think of the outdoor appearance of the kindergarten building (external block)?

The outdoor appearance of the kindergarten building is the first factor in attracting children so it must be of a different shape and distinguishable among the other school buildings. This comes on contrary to the results of the questionnaire in this paragraph where the highest percentage $(45.7 \%)$ for the external shape is traditional and not within the limits of the human scale as kindergarten building .But the lowest percentage is that it is not visually stimulating to attract the child's attention by (5.7\%). (Fig. 3).

2. Is the total area of the kindergarten building sufficient to distribute all the primary and secondary activities?

The results of the questionnaire showed that $(51.4 \%)$ of the respondents indicated that the total area of the kindergarten building is insufficient and $48.6 \%$ of them confirmed that the area is sufficient to distribute all basic and secondary activities. The area is among the standards components of the building of kindergarten school. the area of kindergarten should be proportional to the number of children where the space allocated for each child will be between (1.5) and not more than (4) meters and this is indicated by (Lowenthal, 1996). (Fig. 4).

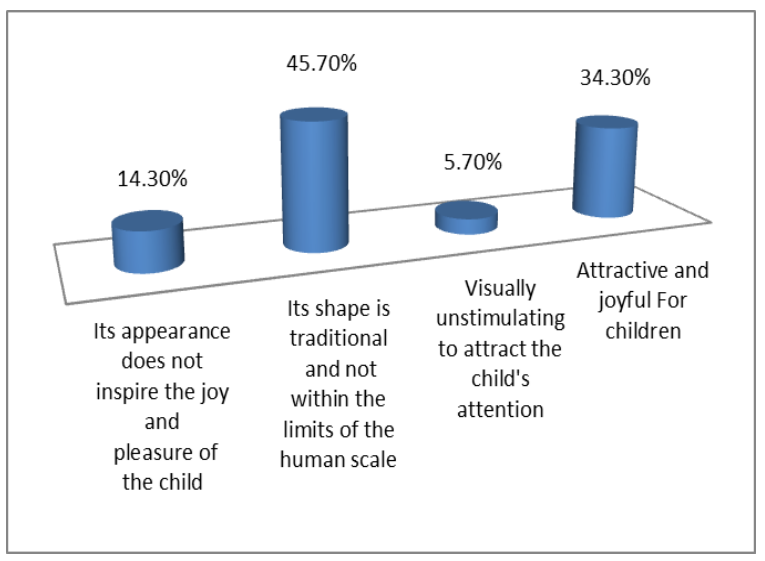

Fig. (3): Exterior appearance of the building. 


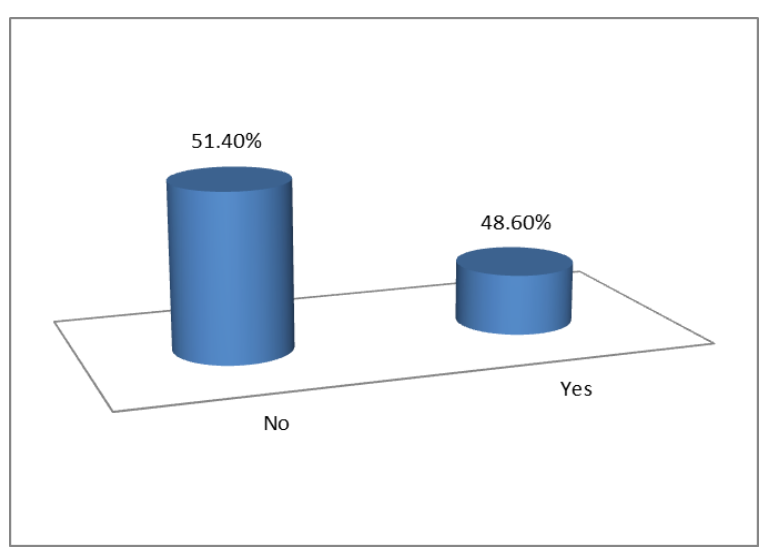

Fig. (4): Total building area.

3. What kind of plants do you want to plant?

The annual flowering plants in the first paragraph of the environmental and natural requirements in the gardens and outdoor spaces of kindergartens schools as in fig. (5) takes the highest percentage in the questionnaire of the sample respondents and reached $(65.7 \%)$ as the type of plants desirable to be cultivated. The researcher insured the need for plant diversity within the outdoor space of kindergarten, because of its psychological, behavioral and functional impact on the behavior of children and this is consistent with (Titman, 1994).

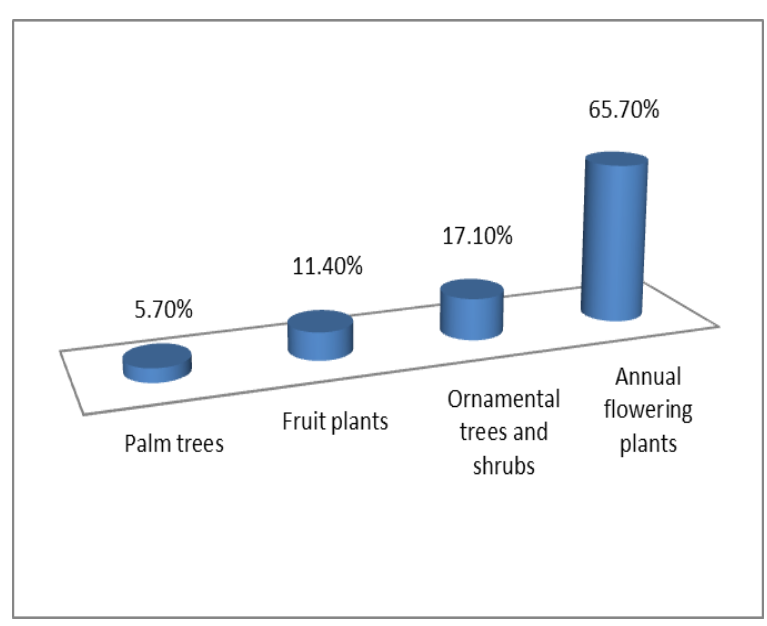

Fig.(5): The plants you want

4. What design model do you find suitable for all activities if you want to allow the freedom of movement in the gardens?
Fig.(6) shows that the most suitable designs in terms of ensuring freedom of movement for all activities for kindergarten school children is the natural design (51.4\%). And according to the results of the questionnaire of the research sample, the free design came with $20.1 \%$ and then the mixed design with $17.1 \%$. Finally, the engineering design comes before the design of the outdoor space environment for kindergartens. The impact of the surrounding environment on the behavior of children and the designer's understanding of their needs must be taken into account when preparing the proposal of the natural design to ensure the child mixing with nature. In this way the child will get the ease of dealing and understanding the surrounding space. As the engineering design is structured, it symmetrically goes boring with the tendencies of the child while the mixed design will be inclusive to the basics of engineering design in terms of organization and containing for ease of natural design and this goes in line with (Hohmann \& Wickart, 1995).

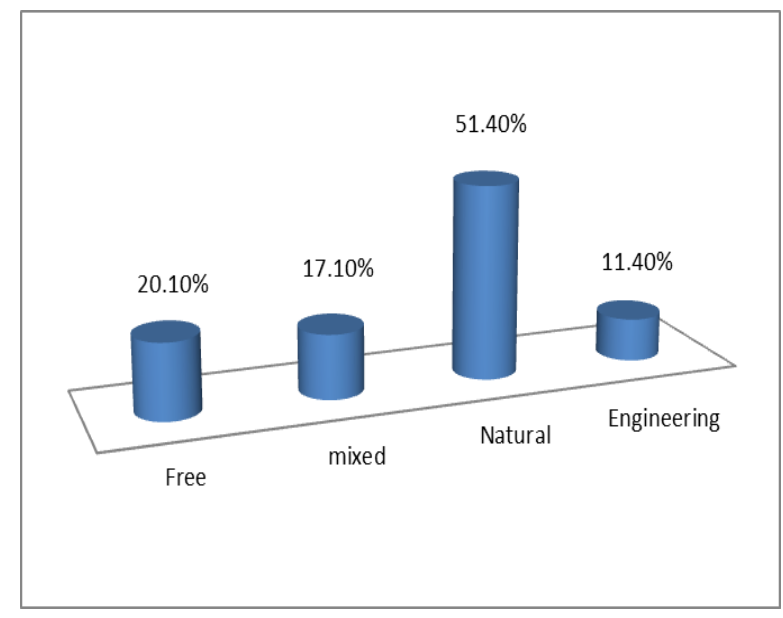

Fig.(6): The appropriate design model

5. What are the actions that lead to encourage the environmental awareness of the children? 
Fig. (7) shows the highest opinion of the members of the research sample on the seventh paragraph of the third dimension that the multiplication and cultivation of plants and care of the work lead to the promotion of environmental awareness among children (57.1\%). Secondly came cleaning the garden and maintenance of mini-games as encouraging works of awareness and thirdly comes pet breeding (14.3\%). As a result of negligence in the works that encourage the environmental awareness among children, the researcher concludes the importance of providing the necessary resources and allocating specific places for activities and works that encourage and increase environmental awareness, such as the allocation of a corner for agriculture and cultivation in pots and plant basins to allow monitoring the stages of plant growth and dependence on natural plants and flowers instead of decorating with natural plants .A corner for pet animals can be added to follow the stages of animal growth and care. This will contributes in achieving the objectives of the approach .It is consistent with Sasila (2010).

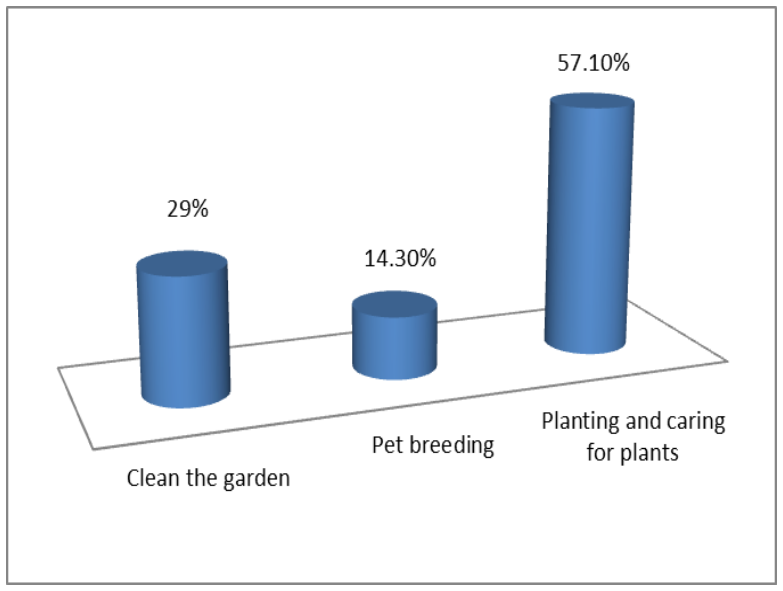

Fig.(7): Promoting environmental awareness

6. What is the preferable playing behavior of children in order to be taken into consideration before designing a kindergarten?
The results of this question were that the child's desire to run and jump is $69 \%$ percentage for the purpose of providing this behavior within the proposed designs for the outdoor space. The other options were somewhat similar and convergent as it is shown in fig. (8) in order to provide them within the proposed designs as a favorable behavior to children. The researcher considers that the different types of toys are of a kinetic activity and a best means that can be exploited to invest the extra energy of the child in a directed and constructive manner towards the child's physical and mental progress which is consistent with Fjørtoft (2004). (Fig. 8).

7. Do you prefer the outdoor play areas to be dedicated to the practice of motor activities?

The impact of the outdoor space environment of kindergartens is not limited to teaching children some skills and refining their experiences, but also to the their mental and physical health as in fig. (9) which shows that $48.6 \%$ of the respondents who preferred the natural shading using plants for outdoor play areas while the respondents who indicated that the outdoor play areas should be covered and shaded with artificial roofs (31.4\%). The remaining sample $(20 \%)$ did not prefer shade, which goes in the same line with and Al-Nashif (2004) and Edas (2005). 


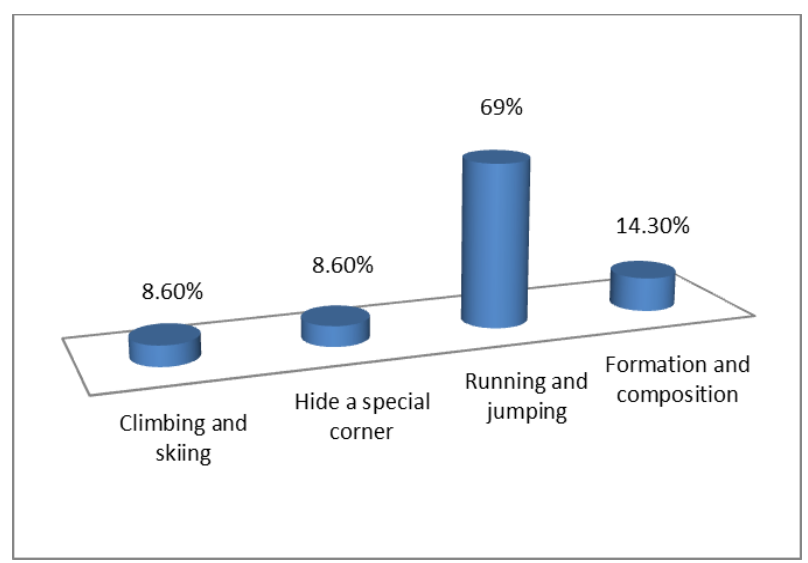

Fig. (8): Granular behavior in children.

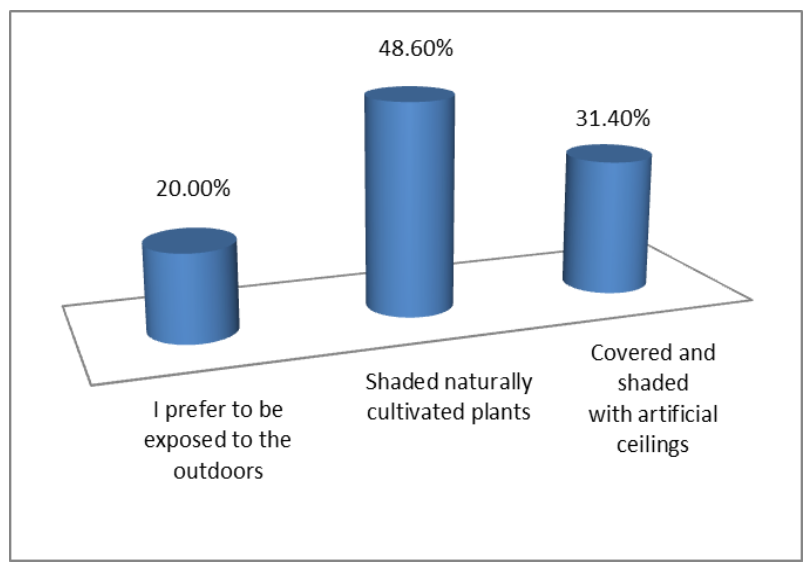

Fig. (9): Outdoor play areas.

8. Do you want to introduce new games to kindergarten like?

Fig. (10) shows the desire of members of the research sample to introduce a theater for the display by $51.4 \%$ percentage as a kind of new games to kindergarten to a large extent, and by (22.9\%) percentage for the establishment of a basketball court or a small football within the outdoor space of the kindergarten and their desire to enter the game of small cars by(17.1\%) Providing new play styles and activities within the outer space to increase the capabilities of the kindergarten. Where the child develops with the presence of other children. Therefore, the quality of the games must be taken into account when Insert a theater for the show tends to participate, and basketball games increase the team play. As for car games, it alerts the child's skill side. This is consistent with Yerkes (1982).

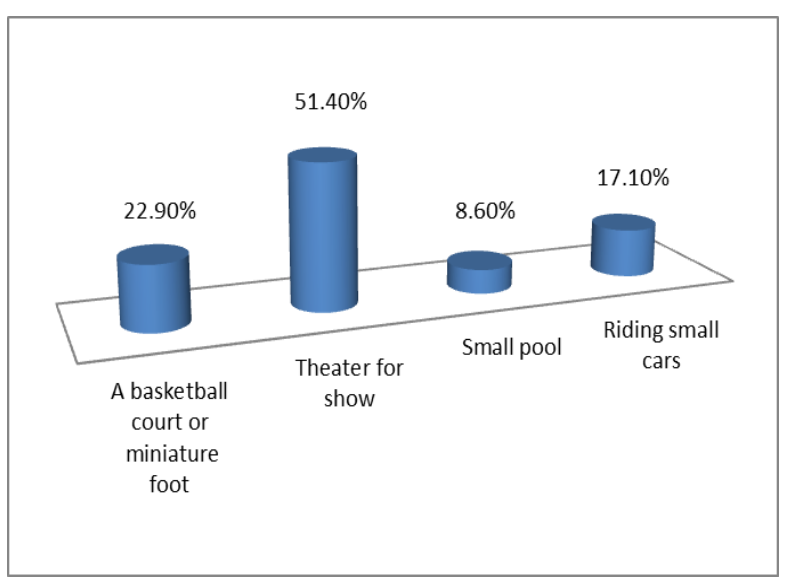

Fig. (10): The type of games children want.

\section{Design Suggestions:}

\section{A. Al-Ashar kindergarten}

The researcher has re-employed the outdoor space for Al-Ashar kindergarten as a better sample allocating with different elements for attractive activities to the child through the design of special characters by establishing small units within the outdoor space and she gave the following suggestions to this purpose:

1- The design of the outdoor spaces confined behind the rows in the classes as specific corners in which a corner was allocated to the sand and for animals' farming. And a special corner was devoted to the theater. The theater was included and formed with adjacent seats arranged in the open air. )Scheme 3).

2- The corner of the games was added to the other corners containing a number of equipped games and sustainability games such as wheels. The floor of the play corner was furnished with soft sand to provide safety when children fall during play. there was a gardening and plantations corner to develop the technical and 
professional abilities of children and encourage them on environmental business.

3- To meet the desire of the respondents, a football field is designed within the outdoor space and a number of terraces are set for children in order to sit.

4- Providing the kindergarten with planting of local trees to reduce the noise, because the kindergarten is bounded by two side streets and on the third side is a main street.

5- The outdoor space within the back of the kindergarten was designed in a Coordinated manner where the flower ponds are distributed on opposite form facing each other. The floor was covered with a green grass and provided with two large umbrellas and a set of games. )Scheme 3-b).

6- The entrance garden was distinctive and attractive interspersed with corridors in order to reach the end of the park and contained a number of games. (Scheme 3-a).

7- The water element should be added in a form of a mini fountain to the entrance of the garden which is surrounded by a colored stone fence.

8- The entrance was a stone space containing a number of seats and on the side of the entrance a number of low bushes were distributed to add joy and planting element to the design.

\section{B. Al-Yassemin kindergarten}

The outdoor spaces of Al-Yassemin kindergarten are wide but neglected. The geographical location of the kindergarten is in a commercial area, bordered by two main streets and on the other side of it is a secondary street which increases the percentage of smoke and harmful fumes; therefore, the proposal was designed in a way due to the desire of the respondents and the determinants as follows:

1- The front part of the outdoor space is designed on both sides of the building with aesthetic gardens that provide on the right side a green area through which a tiled corridor passes through the side gate to reach the building. In the middle was a low fountain, and the remaining space for this side was left without furniture, so that it would be a free-toplay area that guarantees freedom of movement and enjoyment as planned while the left side was clad with Green grass. A number of terraces and games are distributed with a stone basin in the middle designed for the cultivation of annual flowers and a number of low shrubs with short integrated growth.

2- Within the design, there is a distribution of play corners on the perimeter of the building such as the corner of gardening work, the corner of sand, corner breeding and attention to pets. (Scheme 4).

3- Providing a rest area surrounded by flowers with a basin in the middle and shaded terraces to sit within the back of the kindergarten and this is an area for outdoor education and nature. (Scheme 4-b).

4- Providing a regular playing area for football and basketball, and seating for spectator children. (Scheme 4-a). 
Al Thiabi \& Al-Samray / Basrah J. Agric. Sci., 33(1): 50-67, 2020

\begin{tabular}{|c|c|c|c|c|c|c|c|c|c|c|c|c|c|c|c|}
\hline & f & 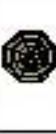 & 2 & $\Leftrightarrow 3$ & & & 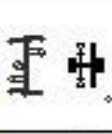 & & & & & & $\Leftrightarrow$ & 7 & 을 \\
\hline & 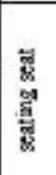 & 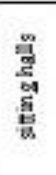 & 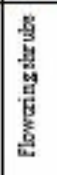 & 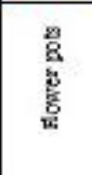 & 䚄 & 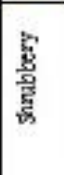 & 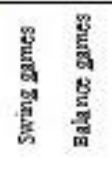 & 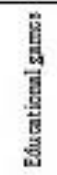 & 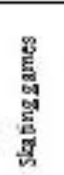 & 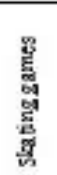 & 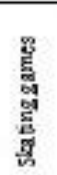 & 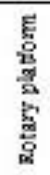 & 勉 & 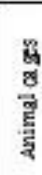 & 岁 \\
\hline
\end{tabular}

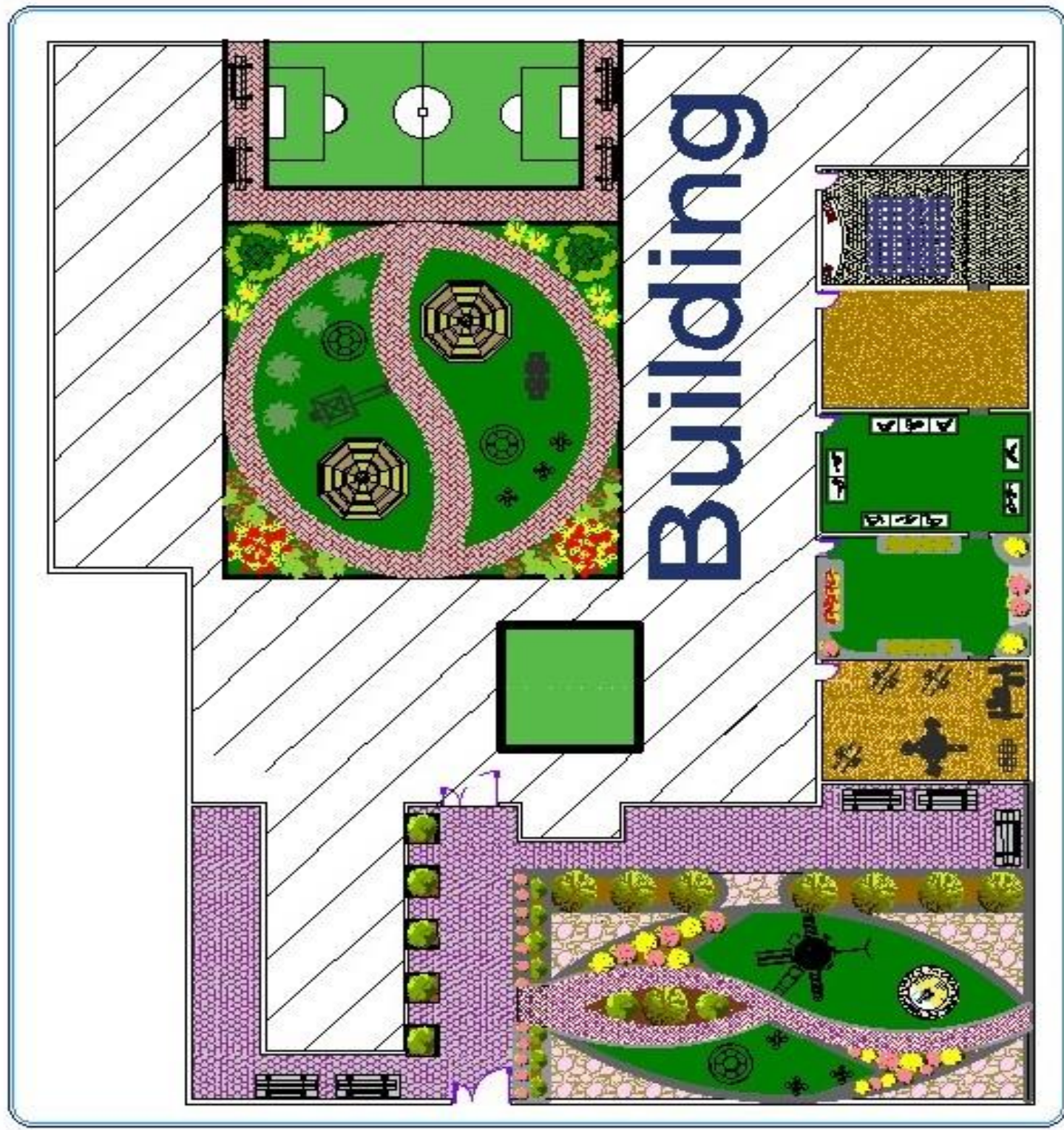

Scheme (3): Al-Ashar kindergarten design. 
Al Thiabi \& Al-Samray / Basrah J. Agric. Sci., 33(1): 50-67, 2020

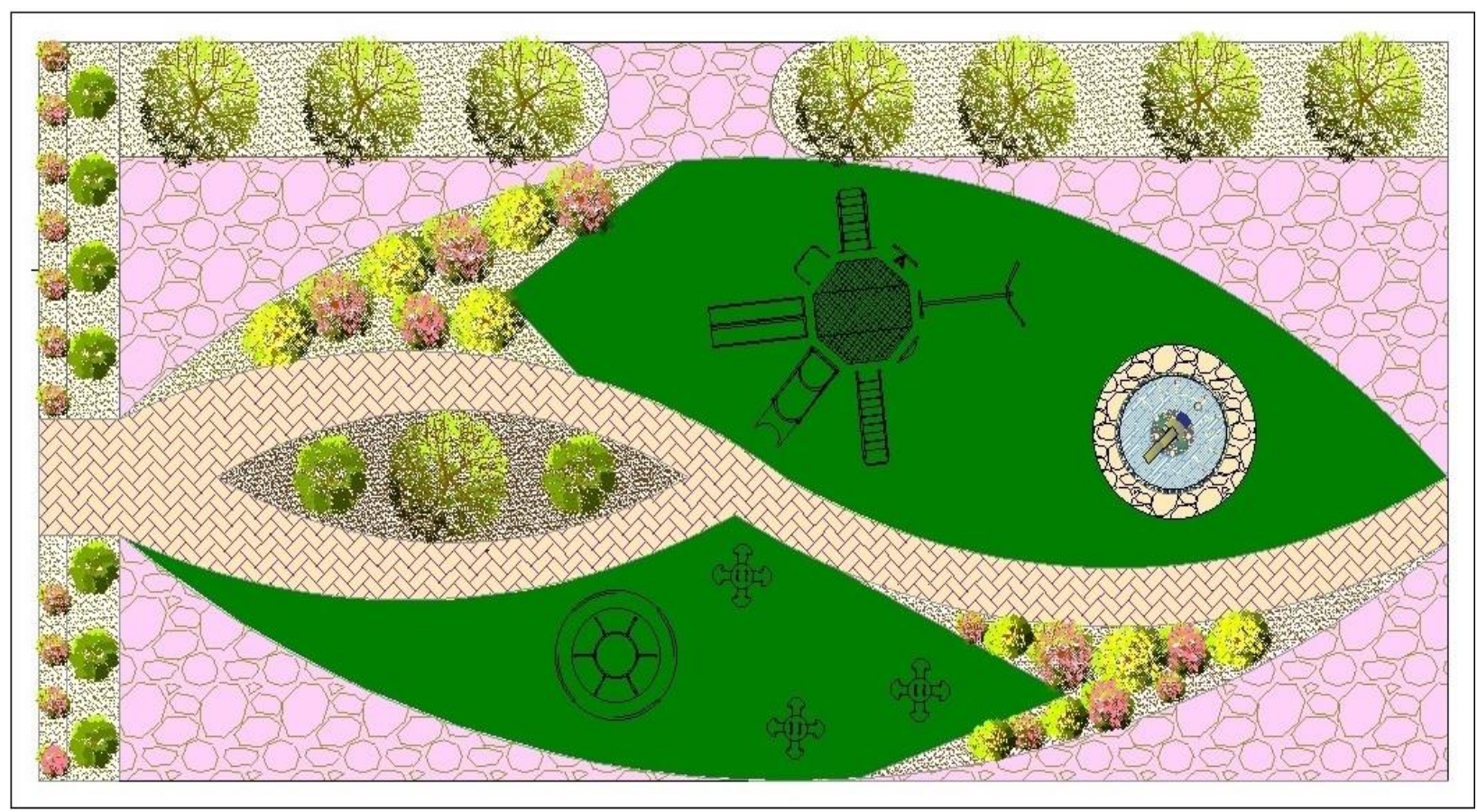

Scheme (3-a): The entrance garden of Al-Ashar kindergarten.

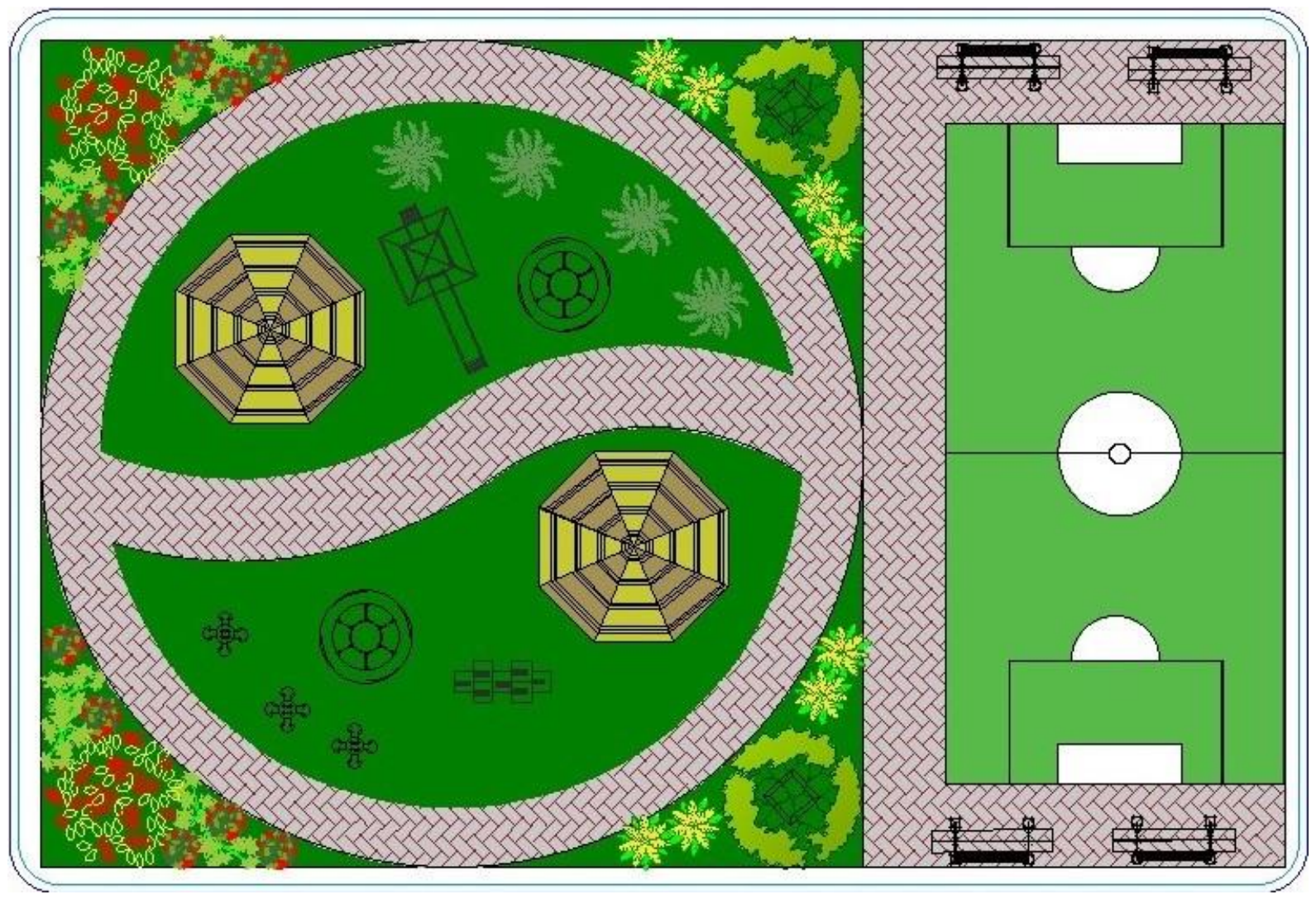

Scheme (3-b): Rear Outer Space of Al-Ashar kindergarten. 
Al Thiabi \& Al-Samray / Basrah J. Agric. Sci., 33(1): 50-67, 2020

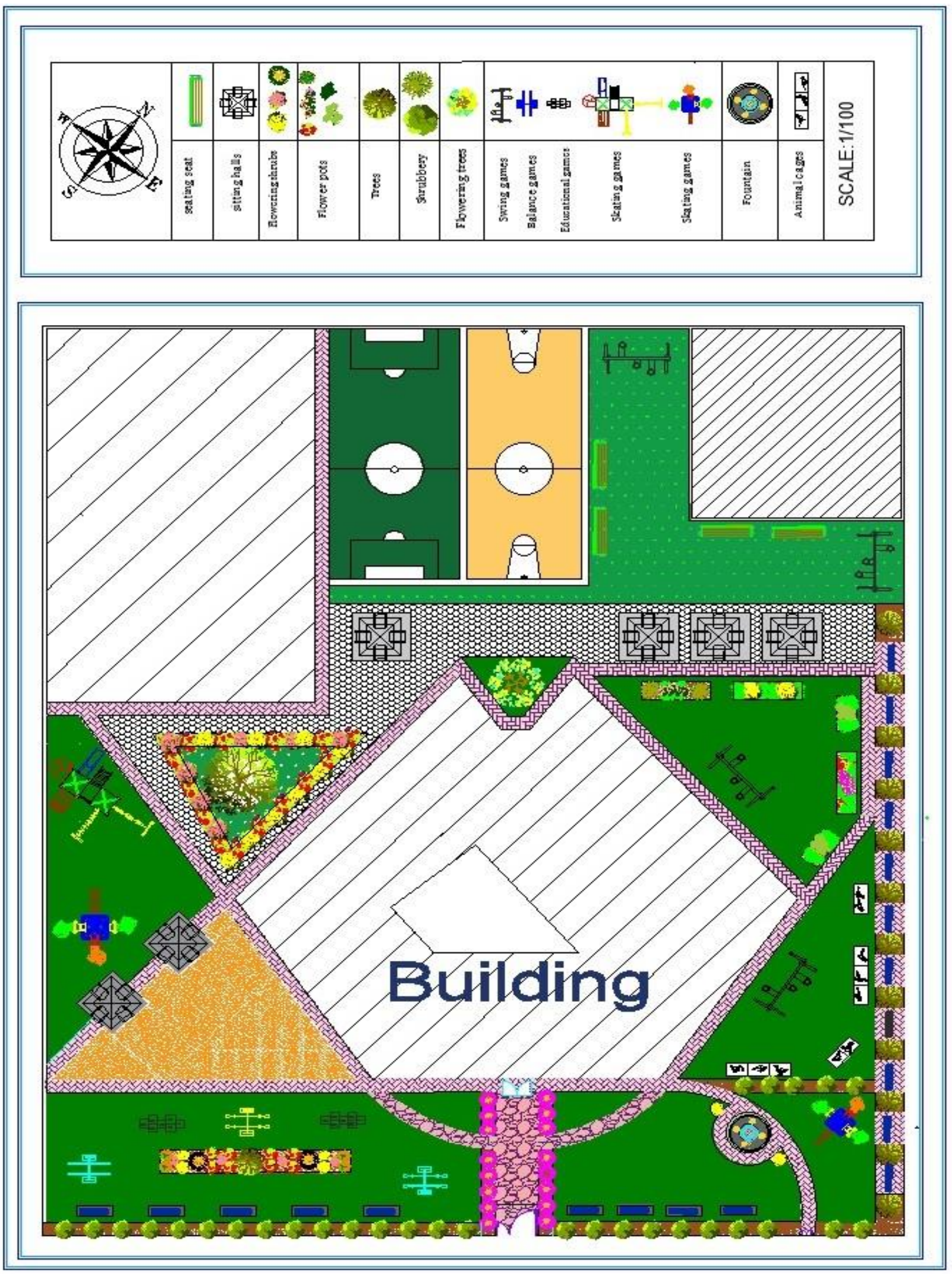

Scheme (4): Al-Yassemin kindergarten design. 
Al Thiabi \& Al-Samray / Basrah J. Agric. Sci., 33(1): 50-67, 2020

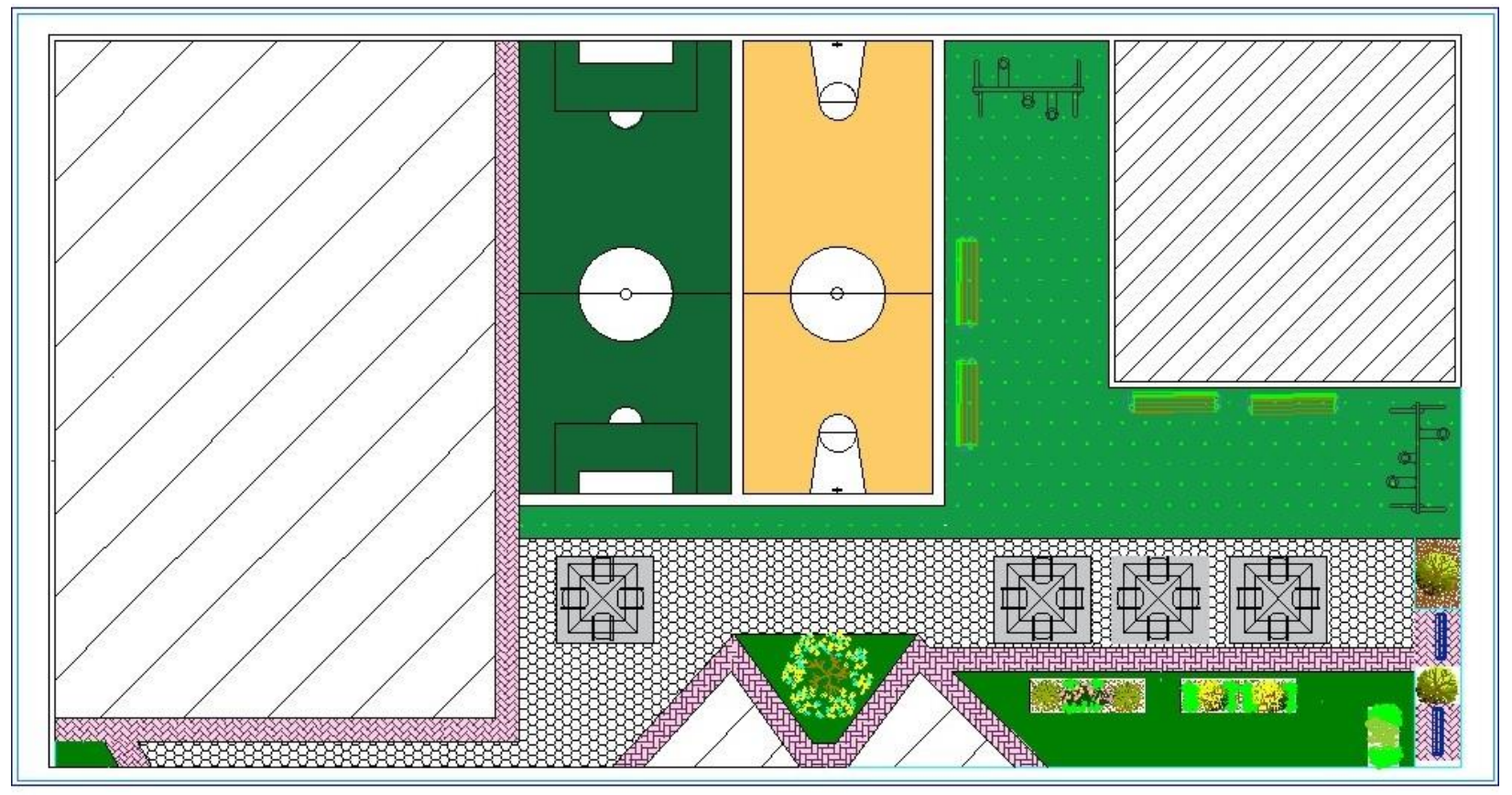

Scheme (4-a): Rear Outer Space of Al-Yassemin kindergarten.

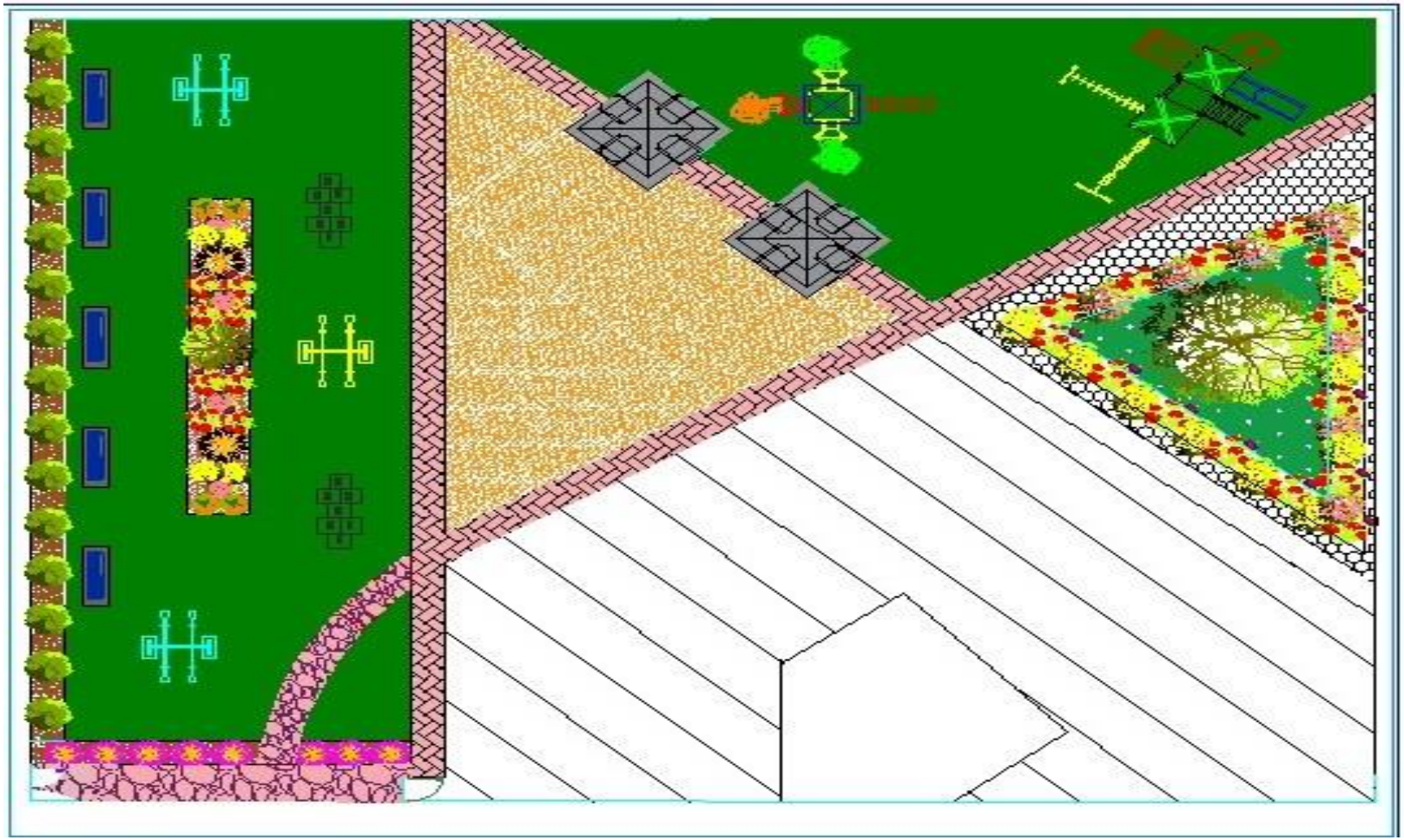

Scheme (4-b): The left side of outer space of Al-Yassemin kindergarten. 
5- The researcher suggests planting a fence of trees as a plant fence which branches are resistant to breakage and rapid renewal of its vegetative branches and taking into account the non-planting of the toxic trees. This plant fence will play a role in the aesthetic, environmental and functional aspects such as reducing environmental pollution and providing psychological comfort to children . In addition to that it participates actively in reducing the noise from the outside

\section{Conclusions}

1. The lack of outdoor spaces in kindergartens for recreational spaces and educational elements causes them to be free from the elements of suspense, exploration and adventure element which are preferred by children.

2. Transforming spaces from outdoor spaces into abandoned and inactive spaces will affect the adequacy of the kindergarten in all environmental, aesthetic and functional aspects, due to the absence of the design element of these spaces.

3. Lack of proper furnishings of games, roofing and good standards related to the specifications of the furnishing which is available in kindergarten schools will weaken the efficiency of external spaces functionally.

4. The percentage of afforestation and vegetation cover are not satisfactory for most of the selected kindergarten buildings.

\section{Acknowledgments}

We pleased to extend our thanks and appreciation to staff of Department of Horticulture and Landscape for support the work.

\section{Conflicts of interest}

The authors-declare-that they-have-no-conflict of interests.

\section{References}

Al-Lagany, F.A.H. (1989). Childhood Between Kindergarten and Education. Al-Falah Library: 393pp. (In Arabic).

Al-Nashif, H.M. (2004). Kindergarten Programs. $1^{\text {st }}$ ed., Dar Al Fikr Publ. Distribution. Oman: 304pp. (In Arabic).

Al-Nawaiseh, A.A. \& Al-Qatawneh, I.T. (2015). Language and Cognitive Growth of Children. Arab Society Library for Publ. Distribution: 230pp. (In Arabic).

Bloom, B.S. (1956). Taxonomy of Educational Objective; the Classification of Educational Goals. Longmans, New York: 216pp.

Dober, R.P. (2000). Campus Design. John Wiley and Sons, New York: 304pp.

Edas, M.A. (2005). Introduction to Kindergarten. $2^{\text {nd }}$ ed., Dar Al-Fikr for Publ. Distribution: 436pp. (In Arabic).

Fjørtoft, I. (2004). Landscape as playscape: The effects of natural environments on children's play and motor development. Children. Youth Environ, 14(2): 21-44.

Franck, K.A. (1985). Social construction of the physical environment: The case of gender. socio-logical focus. Struct. Environ. Women Changing Roles, 18(2): 143-160.

Hohmann, M. \& Wickart, D. (1995). Educating Young Children: Active Learning Practices for Preschool and Child Care Programs. Publishing for Arabic Printing, The Jordanian Books Center: 686pp. Translated to Arabic by Mohammed S. Khattab. 
Al Thiabi \& Al-Samray / Basrah J. Agric. Sci., 33(1): 50-67, 2020

Khalaf, A.E. (2015) Introduction to Kindergarten. $2^{\text {nd }}$ ed., Library World, Cairo: 228pp. (In Arabic).

Lowenthal, B. (1996). Teaching social skills to preschoolers with special needs. Child. Educ., 72(3):137-140.

Mardan, N.A.; Sharif, N.M. \& Abdel Aal, S.E. (2004). Educational Reference for Kindergarten Programs. Arab Organization for Education, Culture and Science: 466pp. (In Arabic).

Marlowe, O.C. (1977). Outdoor Design. A Handbook for the Architect and Planner, London: 316pp.

Sasila, R. (2010). A proposed concept for ensuring the quality of the educational environment in Kindergartens in the Syrian
Arab Republic, Damascus Univ. J., 26(3): 235-280. (In Arabic).

Taylor, A.F.; Wiley, A.; Kuo, F.E. \& Sullivan, W.C. (1998). Growing Up in the Inner City: Green spaces as places to grow. Environ. Behav., 30(1): 3-27.

Titman, W. )1994(. Special Places; Special People: The Hidden Curriculum of School Grounds. Surrey: 164pp.

Yerkes, R. (1982). A Playground That Extends The Classroom, Miami University, ERIC. Document Reproduction. Article ID 239802. 6(4): 8pp.

Y1ldırım, G. \& Akamca, G.Ö. (2017). The effect of outdoor learning activities on the development of preschool children. South Afr. J. Educ., 37(2): 1378, 10pp.

\section{التخطيط والتصميم الامثل للفضاءات الخارجية المفتوحة لرياض الاطفال في محافظة البصرة (روضة الياسمين وروضة العشار كحالة دراسية)

المستخلص: تلعب مباني رياض الاطفال دوراً مهماً في الهجمع لدورها في تأهيل الطفل للالتحاق بالمرحلة الابتدائية حيث تعتبر رياض الاطفال أول اتصال اجتماعي حقيقي منظم للطفل بالعالم الخارجي لأطلاق الطاقة الحركية والابداعية والفكرية وبيان العلاقة

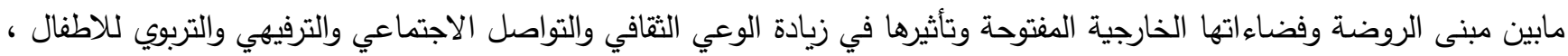
لقد قدمت الباحثة التصاميم المقترحة باستخدام التقنيات الحديثة برنامج ( AutoCAD ) وتتأمل الباحثة ان تكون هذه الدراسة جزءاً من المخططات المستقبلية في تخطيط وتصميم الفضاءات الخارجية المفتوحة لمباني رياض اطفال شاملة للأسس والمعايير العالمية للطفولة . الكلمات المفتاحية : الفضاءات الخارجية لرياض الاطفال، التصميم الامثل لرياض الاطفال، المقترحات التصميمية. 